Jurnal Teknik Komputer AMIK BSI

Volume 8, No.1, Januari 2022

P-ISSN 2442-2436, E-ISSN: 2550-0120

Akreditasi Ristekdikti, No: 36/E/KPT/2019 (Sinta 4)

DOI: $10.31294 /$ jtk.v4i2

\title{
Aplikasi E-News Untuk Informasi Berita Teknologi Komputer Dengan Pendekatan Classic Life Cycle Model
}

\author{
Susafaati $^{1}$, Nunung Hidayatun ${ }^{2}$, Hidayanti Murtina ${ }^{3}$ \\ ${ }^{1,3}$ Universitas Nusa Mandiri/Teknik Informatika \\ e-mail: hidayanti.hym@nusamandiri.ac.id \\ e-main: susafa.suf@nusamandiri.ac.id \\ ${ }^{2}$ Universitas Bina Sarana Informatika/Sistem Informasi \\ e-mail: nunung.ntn@bsi.ac.id

\begin{tabular}{ccc}
\hline Diterima & Direvisi & Disetujui \\
$25-09-2021$ & $28-12-2021$ & $11-01-2022$ \\
\hline
\end{tabular}

\begin{abstract}
Abstrak - Teknologi saat ini telah mengalami perkembangan sangat pesat terutama teknologi komputer, sehingga mempunyai dampak dalam meningkatkan efektifitas dan keefisienan dalam pekerjaan. Begitu juga dengan teknologi informasi dan komunikasi khususnya internet yang mendorong penyebaran suatu informasi atau berita yang lebih luas dan teknologi yang digunakan untuk menyampaikan kebutuhan masyarakat akan berita yang mudah diakses dan up to date yaitu menggunakan website portal berita. Walaupun dengan teknologi yang maju, tak sedikit dikalangan masyarakat yang masih tidak tahu dalam mengoperasikan komputer. Oleh karena itu penulis tertarik untuk untuk membuat sebuah website portal berita teknologi komputer. Tujuan dari penelitian ini adalah mampu membangun web yang dapat menjadikan sumber informasi bagi masyarakat untuk lebih mengenal dan mengetahui cara pengoperasian komputer dengan benar. Dan metode yang digunakan pada perancangan web meliputi observasi dan studi pustaka, analisis, perancangan, testing (pengujian) serta metode pengembangan sistem menggunakan pendekatan Classic Life Cycle Model . Hasil dari penelitan adalah suatu sistem informasi portal berita online yang dapat melakukan penyebaran berita atau informasi tentang teknologi komputer melalui media internet..
\end{abstract}

Kata Kunci: Teknologi Komputer, Website Portal Berita, Internet

\begin{abstract}
Current technology has undergone rapid development especially komputer technology, so it has an impact in increasing the effectiveness and efficient in work. As well as information and communication technology especially the internet that encourages the dissemination of an information or news that is wider and the technology used to convey the needs of the community will be news that is easily accessible and up to date news portal website using IE. Despite its advanced technology, not a few among the public who still do not know in operating the komputer. Therefore, the authors are interested in to make a website portal news komputer technology. The purpose of this research was able to build a web that can render the information source for the public to better recognize and know how to operate the komputer correctly. And methods used in the design of the web include the observation and study of the literature, analysis, design, testing (testing) as well as modeling technique which is described with the Unifield Modeling Language (UML). The expected results are can do spread the news or information about komputer technology through the medium of the internet.
\end{abstract}

Keywords: Komputer Technology, Internet News Portal Website

\section{PENDAHULUAN}

Teknologi internet pada saat ini telah berkembang sangat pesat dan telah mampu mengubah wajah komunikasi dunia yang awalnya non-digital, menjadi komunikasi digital secara global (Tri Angga et al., 2014). Pesatnya perkembangan teknologi internet tersebut memiliki pengaruh yang besar terhadap kehidupan masyarakat (Nandari, 2014). Bahkan hampir semua belahan dunia memanfaatkan teknologi tersebut untuk mencari dan menyebarkan informasi (Devianto \& Dwiasnati, 2021). Mungkin suatu kenaifan kalau berbicara tentang teknologi, tanpa membicarakan suatu benda yang bernama komputer. Komputer merupakan suatu alat elektronik yang dari waktu ke waktu mengalami

http://ejournal.bsi.ac.id/ejurnal/index.php/jtk 
perkembangan yang begitu cepat, sehingga dalam aspek kehidupan sekarang tidak lepas dari teknologi komputer mulai dari dunia pendidikan, kedokteran, dan pemerintahan hingga dari hal yang paling mendasar dan tidak dapat dipisahkan, sehingga dapat di jumpai di manapun. Namun seiring cepatnya perkembangan teknologi komputer terkadang masyarakat kurang up to date tentang apa-apa saja yang ada dalam teknologi komputer sehingga tak kayal banyak dari kita mengalami gaptek (gagap teknologi) tentang komputer.

Berdasarkan data statistik pengguna internet, per 30 Juni 2012 jumlah pengguna internet dunia mencapai 2,4 milyar lebih dengan penetrasi mencapai 34,3 persen penduduk dunia. Data per 30 Juni 2012 juga menyebutkan jumlah pengguna internet di Indonesia mencapai 55 juta orang. Padahal pada tahun 2000 lalu masih berjumlah 2 juta pengguna. Hal inilah yang kemudian mendukung perkembangan media online di dunia, (Efendi, 2015). Sehingga portal berita atau media online menjadi media utama untuk mendapatkan informasi terkini dan aktual.

Unsur-unsur analisis kerangka Jongdang Pan, seperti sintaksis, penulisan, tema, dan retorika, tidak mengalihkan perhatian atau condong ke satu arah, tetapi memungkinkan pembaca untuk membentuk opininya sendiri atas peristiwa yang diberitakan. (Nurfadillah \& Ardi, 2021) Portal berita bermanfaat yang memudahkan pengguna untuk menambahkan informasi terbaru dan terupdate ke berita mereka. (Nainggolan et al., 2021) Website memudahkan pengelolaan informasi, website ini menawarkan banyak keuntungan bagi masyarakat serta kemudahan dalam pengelolaan sistem informasi bagi operator. (Afriansyah et al., 2020)

Walaupun perkembangan teknologi yang begitu pesat namun masih ada diantara masyarakat yang kurang menguasai teknologi komputer dikarenakan minimnya minat baca masyarakat tentang teknologi komputer sehingga dalam pemanfaatan teknologi komputer dalam membantu pekerjaan masyarakat masih sangat kurang dan terkadang masyarakat masih bingung dalam mengoperasikan komputer bahkan tak jarang ada yang tidak dapat sama sekali mengoperasikan komputer. Salah satu hal yang menyebabkan minimya minat baca masyarakat adalah masih sedikitnya portal-portal berita yang menyajikan berita tentang pentingnya teknologi komputer dan ditambah dengan bentuk penyampaian yang kurang menarik dan sulit dimengerti masyarakat umum.

Tujuan dari penelitian ini adalah merancang suatu sstem informasi portal berita yang dapat membantu masyarakat untuk mendapatkan sumber berita terkait informasi teknologi komputer. Hasil dari pembangunan sistem informasi berbasis web tersebut adalah suatu aplikasi $e$-news.

\section{METODOLOGI PENELITIAN}

Dalam membangun sebuah perangkat lunak dibutuhkan sebuah cara atau metodologi sebagai panduan untuk mendapatkan perangkat lunak yang diharapkan (Pudjiarti et al., 2019) Metodelogi penulis yang digunakan yaitu:

\section{Pengumpulan data}

Pengumpulan data dilakukan dengan cara:

a. Observasi

Penulis melakukan penelitian/pengamatan langsung terhadap web-web seperti kompas.com dan detik.com yang mana web - web tersebut menyampaikan informasi berita melalui media portal berita online, sehingga memperoleh data data yang akurat.

\section{b. Studi Pustaka}

Studi pustaka merupakan metode pengumpulan data dengan cara mengumpulkan data - data dari perpustakaan yang mendukung penelitian baik itu dari buku mengenai website, jurnal, maupun artikel apa saja yang membahas tentang portal berita, PHP dan juga MySQL.

\section{Model Pengembangan Sistem}

Dalam penelitian ini metode yang digunakan adalah metode SDLC dengan Classic Life Cycle Model atau biasa disebut dengan waterfall model. Model ini digunakan karena semua kebutuhan sistem dapat didefinisikan secara lebih utuh, sehingga pengembangan perangkat lunak dapat berjalan dengan baik. Maka kerangka penelitian yang penulis lakukan yaitu:

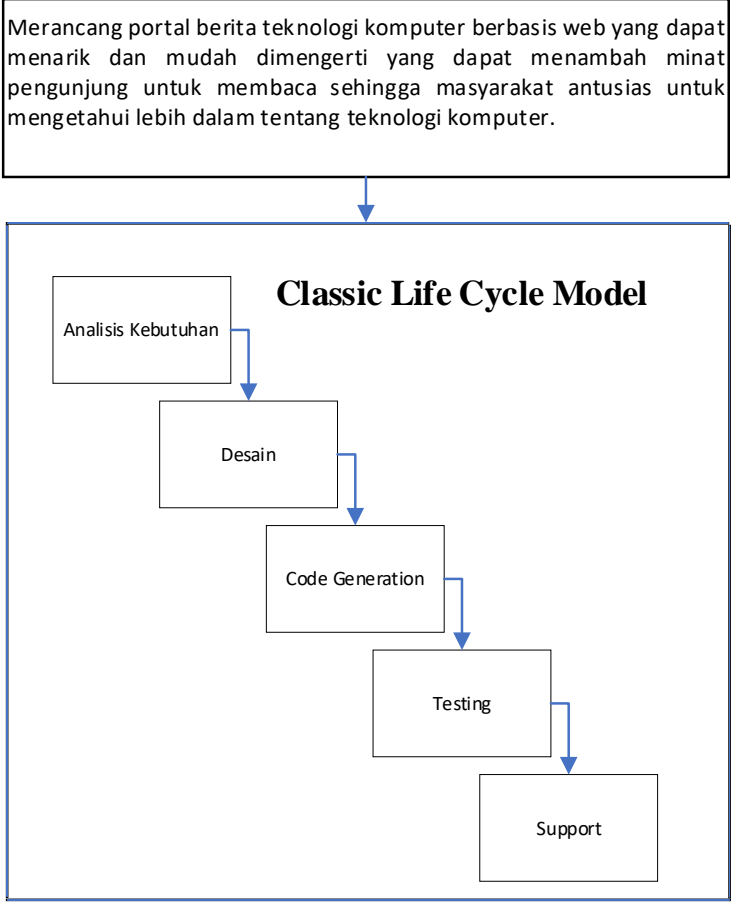


Sumber: Hasil penelitian 2021

Gambar 1. Kerangka penelitan

Berdasarkan kerangka penelitian pada gambar 1, tahapan dari perancangan sistem informasi portal berita teknologi komputer berbasis web adalah sebagai berikut:

A. Analisa kebutuhan sistem

Pada tahap analisa kebutuhan sistem ini penulis melakukan analisa terhadap sistem yang saat ini sedang berjalan agar penulis dapat memahami proses yang terjadi dengan baik. Dan juga penulis menganalisa kebutuhan termasuk dokumen dan interface yang diperlukan guna menentukan solusi piranti lunak (software) yang diperlukan dan digunakan oleh penulis untuk mempermudah dalam membuat portal berita teknologi komputer berbasis web.

B. Desain

Pada tahap ini penulis mendefinisikan kebutuhan sistem yang terkait dengan pengembangan program. Proses ini meliputi beberapa hal yaitu rancangan database yang digunakan adalah Entity relationship diagram (ERD), dan untuk merancang sistem dalam pengembangan program portal berita teknologi komputer yang akan dijelaskan menggunakan UML (Unifield Modeling Language) yang terdiri dari activity diagram, component diagram use case diagram dan deployment diagram.

C. Code Generation

Code generation (pengkodean) merupakan tahapan penerjemah disain sistem yang telah dibuat ke dalam bentuk perintah yang dimengerti komputer. Dalam penentuan bahasa pemrograman saat melakukan perancangan portal berita teknologi komputer, penulis membuat pemrograman terstruktur dengan menggunakan bahasa pemrograman PHP, HTML, Javascript dengan menggunakan aplikasi adobe dreamwever CS5.

D. Testing

Setelah melakukan tahap pemrograman tahap selanjutnya adalah tahap pengujian (testing) sistem secara meneyeluruh dari sistem informasi portal berita teknologi komputer yang telah dirancang, dan pengujian yang dilakukan dengan menggunakan blackbox testing yaitu pengujian dilakukan tanpa melihat source code program dan dijalankan oleh user untuk mengamati apakah program portal berita teknologi komputer sudah sesuai dengan yang diinginkan.

E. Support

Tahapan ini diperlukan jika kemudian hari terjadi kerusakan ataupun kesalahan (bugs) dari software yang telah dibangun. Sehingga dimasa mendatang diperlukan pembaharuan (update) software yang dapat mengurangi kesalahan (bugs) dan membuat tampilan serta kontenkonten yang ada menjadi lebih menarik dan interkatif. Oleh karena itu perlu adanya upaya peningkatan memory RAM, kapasitas Hardisk, dan kualitas VGA card, sehingga tampilan dan prosess dari penggunaan website lebih cepat dan tampilan yang lebih baik.

\section{HASIL DAN PEMBAHASAN}

1. Analisis Kebutuhan Sistem

A. Analisis Kebutuhan Pengguna

Sistem portal berita berbasis web dimana pembaca dapat membaca berita secara online dan pada bagian pengelola meliputi IT admin, editor, wartawan mampu menyediakan berita untuk user. Pembaca dapat membaca melalui media browser. Berikut ini spesifikasi kebutuhan (system requirement) dari perancangan portal berita teknologi komputer berbasis web:

1) Pembaca dapat dapat memilih berita yang akan dibaca berdasarkan kategori, mendaftar menjadi member (pelanggan), melakukan login, menulis komentar pada berita.

2) IT admin dapat mengelola data admin, penyunting, wartawan, dapat menyetujui permintaan pembaca menjadi pelanggan (member), dapat menyaring komentar dari pelanggan kemudian menampilkan komentar.

3) Penyunting dapat mengedit dan menghapus berita, mempublikasikan berita, mengelola ketegori berita.

4) Wartawan dapat menambah dan menghapus berita

\section{B. Usecase Diagram}

1) Usecase Diagram halaman pembaca.

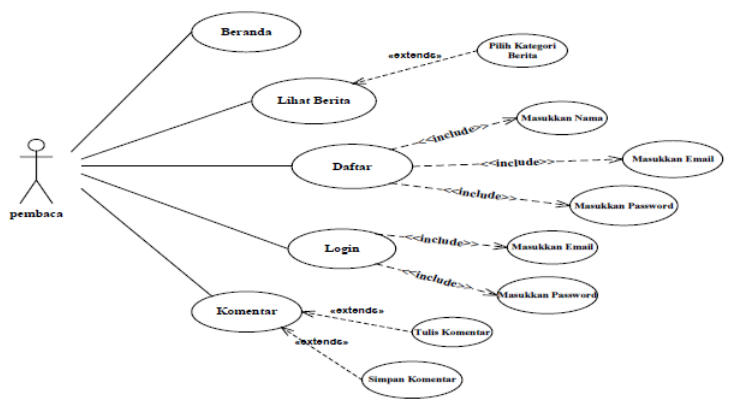

Gambar 2. Usecase Diagram Portal Berita Pembaca

2) Usecase diagram halaman IT admin

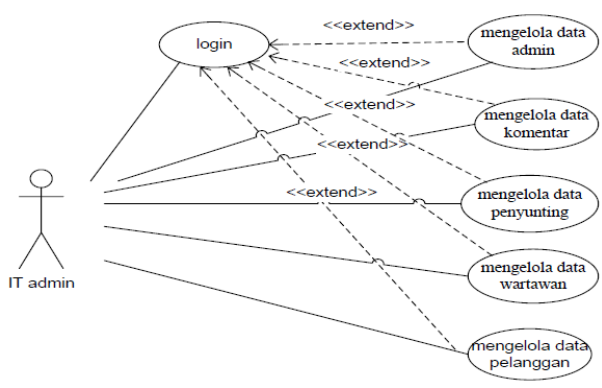

Gambar 3. Usecase portal berita IT admin 
3) Usecase diagram Halaman penyunting

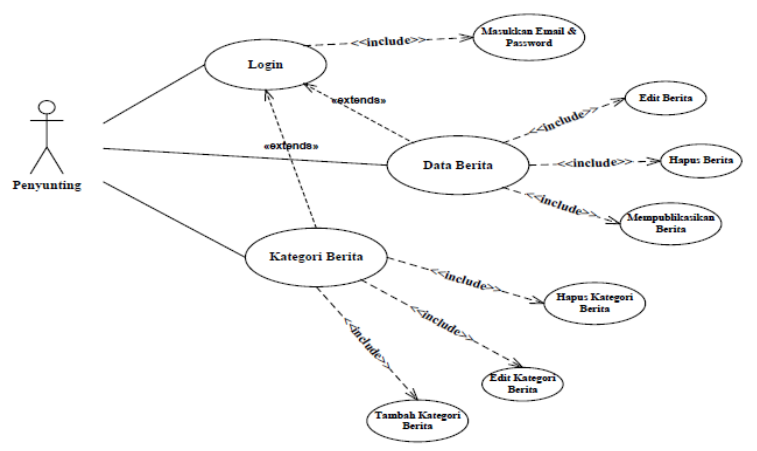

Gambar 4. Usecase Portal Berita Penyunting

4) Usecase diagram Halaman wartawan

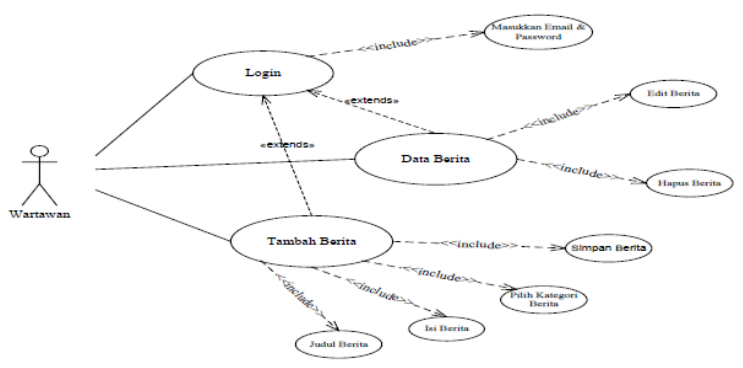

Gambar 5. Usecase Portal Berita Wartawan

2. Desain

A. Database

Desain database yang efektif memungkinkan hasil aplikasi yang berjalan dengan baik (Hidayatun et al., 2017). Pada tahapan desain database meliputi:

1) ERD (Entity relationship diagram)

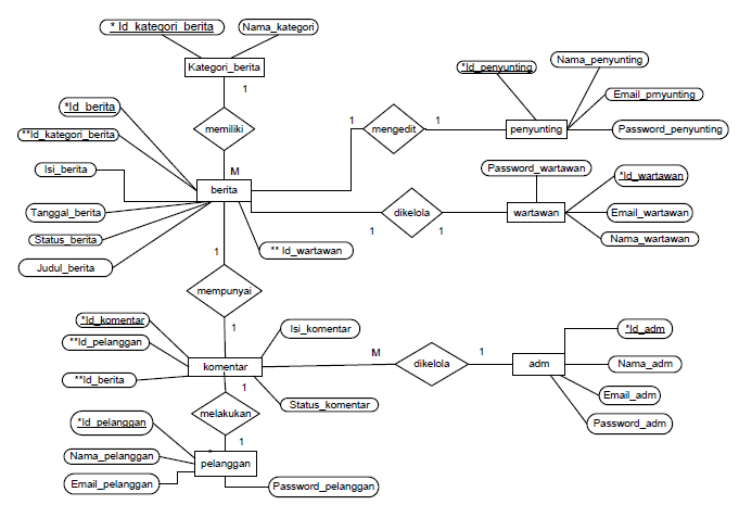

Gambar 6. ERD (Entity relationship diagram)

\section{2) LRS (Logical Relational Structure)}

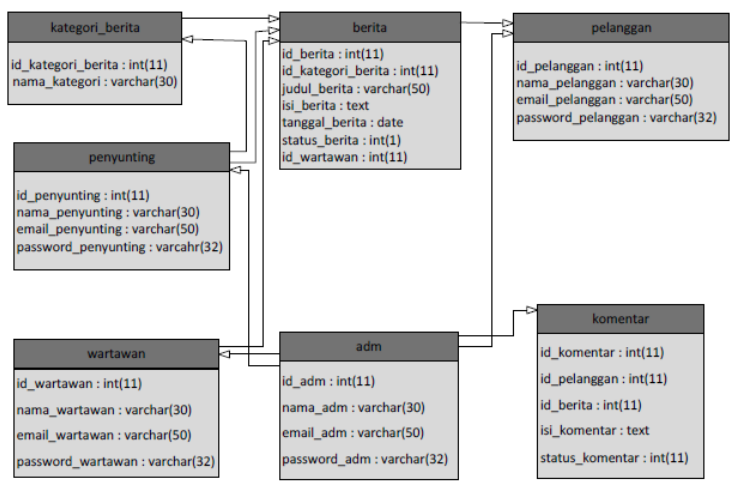

Gambar 7. Logical Relational Structure

\section{B. Software Architecture}

Dalam bagian ini Software Architecture akan menggambarkan bagaimana sistem dari software tersebut dapat dipetakan. Dalam bagian ini akan dijelaskan dalam dua bagian yaitu Deployment diagram dan Component diagram. Berikut penjabarannya dari Software Architecture:

1) Deployment Diagram

Deployment Diagram dalam sistem ini menggambarkan bagaimana sistem website portal berita teknologi komputer secara fisik terlihat.

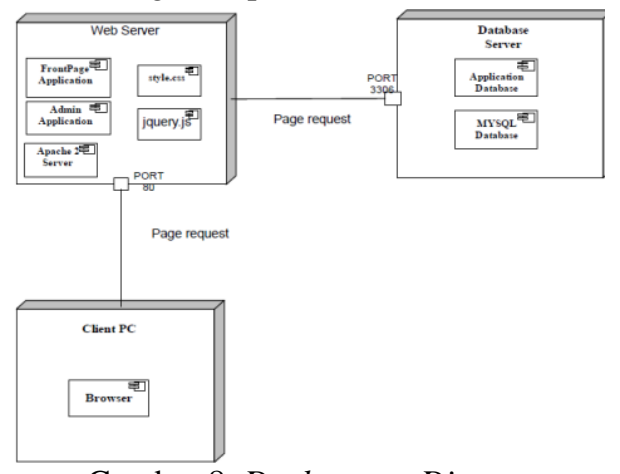

Gambar 8. Deployment Diagram

2) Component Diagram

Component Diagram yaitu menggambarkan paket fisik dari modul pengkodean dan menunjukkan interface yang digunakan untuk berkomunikasi antar komponen (Maulana et al., 2019).

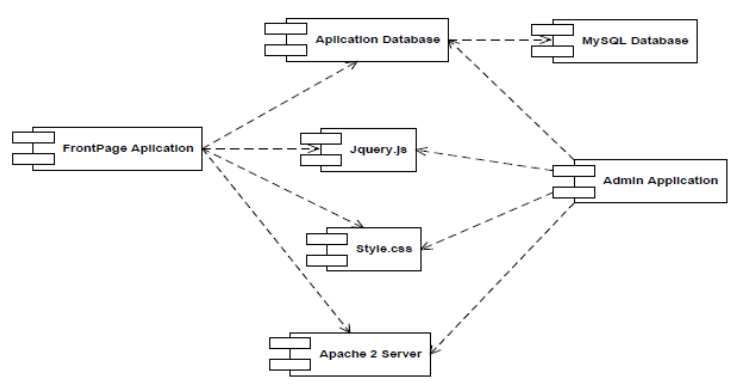

Gambar 9. Component diagram

C. User Interface

1) User interface pada halaman pembaca 
Pada bagian ini akan menampilkan tentang user interface pada bagian pelanggan yang meliputi halaman beranda, halaman daftar pelanggan, halaman login pelanggan, dan halam untuk berkomentar. Gambar 10 adalah tampilan halaman beranda untuk pembaca:

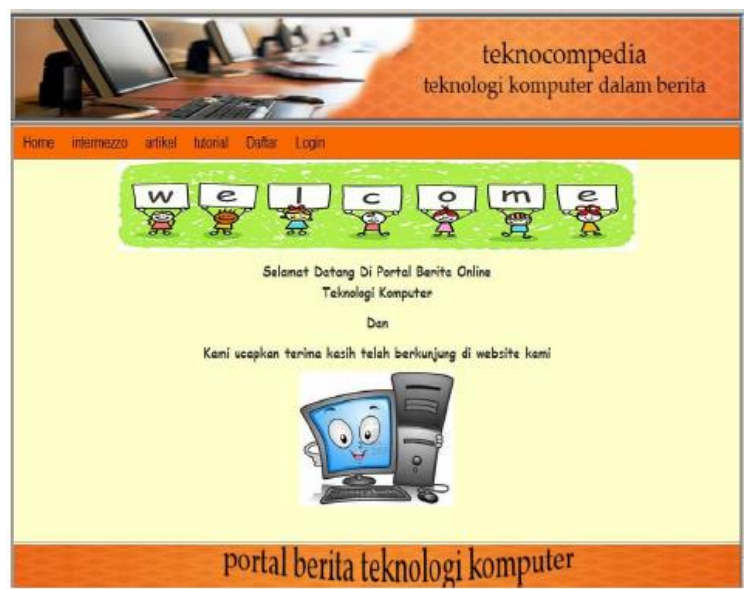

Gambar 10. User interface beranda pembaca

2) User interface pada halaman pengelola

Pada bagian ini akan menampilkan tentang user interface pada bagian pengelola yang meliputi, halaman IT admin, halaman penyunting, wartawan. Gambar 11 merupakan halaman pengelolaan data admin di ruang IT admin:

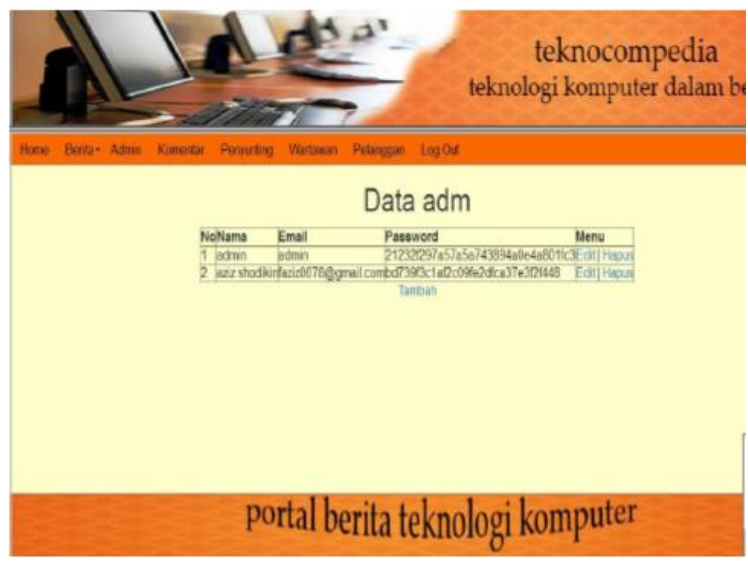

Gambar 11. User interface data admin halaman IT admin

Gambar 12 Merupakan halaman yang menampilkan form edit berita pada halaman penyunting:

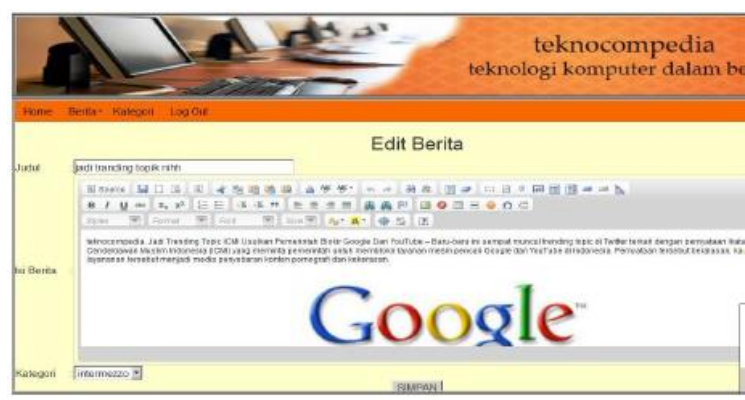

Gambar 12. User interface form edit berita halaman

$$
\text { penyunting }
$$

Gambar 13 Merupakan halaman yang menampilkan form tambah berita:

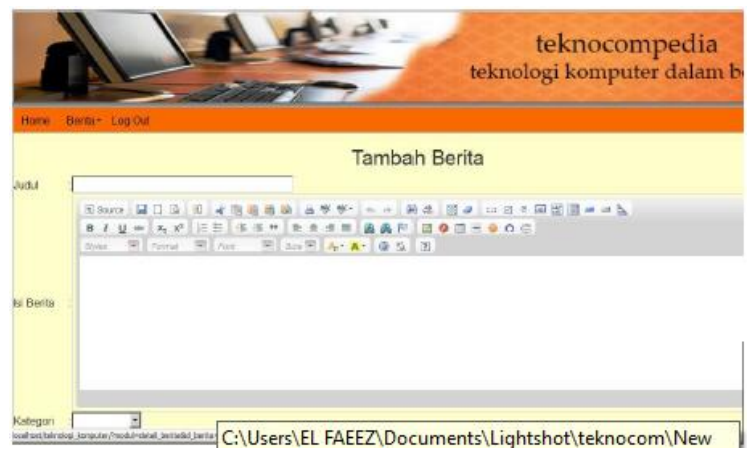

Gambar 13 User interface form tambah berita halaman wartawan

\section{Code Generation}

Tahap code generation adalah tahap dimana desain yang telah dirancang akan ditranslasi ke dalam software. aplikasi e-new menggunakan Bahasa pemrograman php, html dan javascript, serta editor yang digunakan yaitu adobe dreamweaver cs5

4. Testing

Tabel 1 merupakan hasil pengujian dengan menggunakan metode Black Box Testing.

Tabel 1.

Pengujian Halaman Login

\begin{tabular}{|c|c|c|c|c|c|}
\hline No. & $\begin{array}{l}\text { Skenario } \\
\text { pengujian }\end{array}$ & $\begin{array}{l}\text { Test } \\
\text { case }\end{array}$ & $\begin{array}{l}\text { Hasil yang } \\
\text { diharapkan }\end{array}$ & $\begin{array}{c}\text { Hasil } \\
\text { pengujia } \\
n\end{array} \mid$ & $\begin{array}{c}\text { Kesimp } \\
\text { ulan }\end{array}$ \\
\hline 1. & $\mid$\begin{tabular}{ccc} 
User & Id \\
& & dan \\
password & tidak \\
diisi & kemudian \\
klik & \multicolumn{2}{c}{ tombol } \\
\multicolumn{3}{|c|}{ login }
\end{tabular} & $\begin{array}{c}\text { User Id: } \\
\text { (kosong } \\
\text { ) } \\
\\
\text { Passwor } \\
d \text { : } \\
\text { (kosong } \\
\text { (k) }\end{array}$ & $\begin{array}{l}\text { Sistem akan } \\
\text { menolak akses } \\
\text { user } \\
\text { dan } \\
\text { menampilkan } \\
\text { "User Id dan } \\
\text { password tidak } \\
\text { dikenal" }\end{array}$ & $\begin{array}{c}\text { Sesuai } \\
\text { harapan }\end{array}$ & Valid \\
\hline 2. & \begin{tabular}{|cc|}
\multicolumn{2}{|c}{ Mengetikkan } \\
user & ID \\
& dan \\
password & tidak \\
diisi & atau \\
\multicolumn{2}{c}{ kosong } \\
kemudian & klik \\
tombol login
\end{tabular} & $\begin{array}{c}\text { Passwor } \\
d \\
\text { (kosong } \\
\text { ) }\end{array}$ & 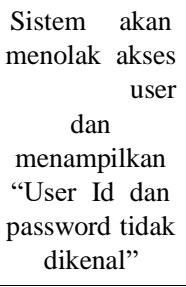 & $\begin{array}{c}\text { Sesuai } \\
\text { harapan }\end{array}$ & Valid \\
\hline 3. & $\begin{array}{c}\text { User ID } \\
\text { tidak diisi } \\
\text { (koso } \\
\text { ng) dan } \\
\text { password diisi } \\
\text { kemudian klik } \\
\text { tombol login }\end{array}$ & $\begin{array}{c}\text { User Id: } \\
\text { (kosong } \\
\text { ) } \\
\\
\text { Passwor } \\
d: \\
1998- \\
03-31\end{array}$ & $\begin{array}{r}\text { Sistem akan } \\
\text { menolak akses } \\
\text { user } \\
\text { dan } \\
\text { menampilkan } \\
\text { "User Id dan } \\
\text { password tidak } \\
\text { dikenal" }\end{array}$ & $\begin{array}{c}\text { Sesuai } \\
\text { harapan }\end{array}$ & Valid \\
\hline
\end{tabular}




\begin{tabular}{|c|c|c|c|c|c|}
\hline 4. & $\begin{array}{c}\text { Mengetikkan } \\
\text { salah satu } \\
\text { kondisi salah } \\
\text { pada user ID atau } \\
\text { password } \\
\text { kemudian klik } \\
\text { tombol login }\end{array}$ & \begin{tabular}{|c|} 
User \\
ID: \\
1001 \\
(benar) \\
\\
Passwor \\
$d: 1998$ \\
$3-31$ \\
(salah)
\end{tabular} & $\begin{array}{c}\text { Sistem akan } \\
\text { menolak akses } \\
\text { user dan } \\
\text { menampilkan } \\
\text { "User Id dan } \\
\text { password tidak } \\
\text { dikenal". }\end{array}$ & \begin{tabular}{|c|} 
Sesuai \\
harapan
\end{tabular} & Valid \\
\hline 5. & $\begin{array}{l}\text { Mengetikkan } \\
\text { user ID dan } \\
\text { password dengan } \\
\text { data yang benar } \\
\text { kemudian klik } \\
\text { tombol login }\end{array}$ & $\begin{array}{c}\begin{array}{c}\text { User } \\
\text { ID: } \\
1001 \\
\text { (benar) }\end{array} \\
\text { Passwor } \\
d: 1998 \\
03-31 \\
\text { (benar) }\end{array}$ & $\begin{array}{l}\text { Sistem menerima } \\
\text { akses login dan } \\
\text { kemudian } \\
\text { langsung } \\
\text { menampilkan } \\
\text { menu utama. }\end{array}$ & $\begin{array}{c}\text { Sesuai } \\
\text { harapan }\end{array}$ & Valid \\
\hline
\end{tabular}

5. Support

a. Mempublikasikan web portal berita

b. Mengupgrade secara berkala hardware dan software

\section{KESIMPULAN}

Kesimpulan dari penelitian ini adalah pembangunan website merupakan sarana yang sangat efektif untuk menyampaikan berita dan khususnya berita tentang teknologi komputer. Sistem informasi berbasis web pun dapat menyediakan informasi dalam bentuk teks ataupun gambar. Serta berdasarkan hasil pengujian menggunakan metode black box, fungsi- fungsi pada aplikasi dapat berjalan sesuai rencana.

\section{REFERENSI}

Afriansyah, R., Mubaroh, S., \& Pratiwi, I. R. (2020). Pembuatan Portal Website Sekolah Sma Negeri 1 Sungailiat Sebagai Media Informasi. Dinamisia: Jurnal Pengabdian Kepada Masyarakat, $\quad 5(1), \quad$ 154-160. https://doi.org/10.31849/dinamisia.v5i1.4413

Devianto, Y., \& Dwiasnati, S. (2021). Rancang
Bangun Web Portal Berita Sebagai Sumber Informasi Berita Tentang Pertanian. JATISI (Jurnal Teknik Informatika Dan Sistem Informasi), 8(2), 534-546. https://doi.org/10.35957/jatisi.v8i2.792

Efendi, J. (2015). Perbandingan Nilai Berita Halaman Depan Portal Berita Riauterkini.Com Dengan Portal Berita Goriau.Com. Jom FISIP, 2(1), 1-12.

Hidayatun, N., Rosmiati, M., \& Saputro, E. (2017). Aplikasi E-Reservation Untuk Pemesanan Kamar Pada Hotel Hin's. Sistem Informasi, 14(1), 57-62.

Maulana, T. D., Nurfauzi, P., Informatika, S., Teknik, F., Majalengka, U., \& Belakang, L. (2019). Rancang Bangun Aplikasi Portal Berita Desa Berbasis. 1-6.

Nainggolan, G. F. H., Andryana, S., \& Gunaryati, A. (2021). Pencarian Berita Pada Web Portal Menggunakan Algoritma Brute Force String Matching. JIPI (Jurnal Ilmiah Penelitian Dan Pembelajaran Informatika), 6(1), 1-10. https://doi.org/10.29100/jipi.v6i1.1824

Nandari, B. A. S. (2014). Pembuatan Website Portal Berita. Indonesian Journal on Networking and Security, 3(3), 1-14.

Nurfadillah, Z., \& Ardi, M. (2021). Analisis Framing Berita Penembakan 6 Laskar FPI Pada Portal Berita Online CNN Indonesia Periode 19 Februari - 03 Maret 2021. Jurnal Komunikasi Islam, 02, 1-14.

Pudjiarti, E., Yana, A. A., \& Hidayatun, N. (2019). Pembangunan e-Commerce Berbasis Web untuk Strategi Penjualan CCTV. Jurnal Sistem Informasi STMIK Antar Bangsa, 8(1), 42-45.

Tri Angga, C., Hamdani, \& Marisa Khairina, D. (2014). Perancangan Aplikasi Content Management System Pada Web Portal Berita Detik Kaltim. Jurnal Informatika Mulawarman, 9(3), 20-27. 